\title{
SHARING AND JUMPING TASK IN COLLABORATIVE TEACHING AND LEARNING PROCESS
}

\author{
Slamet Asari \\ University of Muhammadiyah Gresik \\ asarififi70@yahoo.com
}

\begin{abstract}
Providing material in the forms of task in collaborative teaching and learning process is one way in tapping the potential of the student's ability both on the cognitive, affective or psychomotoric trait.The task material provided in this collaborative learning is to foster a dialogical situation, communicative atmosphere, mutual listening and learning among students. The material itself is an obligatory task which is in accordance with the capacity of each student. Material assignments or tasks in the learning process is not only as an evaluation tool but also as a tool triggering the implementation of the teaching procedures to deliver real results that makes the students understand and learn the actual learning. Therefore, the level of task must be considered to obtain real change for each student learning.
\end{abstract}

Key words: Task, Sharing and Jumping Task, Collaborative

\section{INTRODUCTION}

Collaborative learning may have often we hear and we apply in the teaching and learning process. Collaborative learning for 100 years has been the central feature in the application of learning-based Lesson Study in Japan. According to Manabu (2014), collaborative learning is principally the essence of learning because in reality there is no learning which is done individually may be accomplished. Collaborative learning provide students a right to learn in which students were present in the learning process to get progress in learning and to bring the expected results.

Lots of research results found that collaborative learning provides significant impact on student learning outcomes and learning in general. Fauzi (2013) found that students increased the ability of critical thinking in math after getting collaborative learning model. In line with Fauzi, Agustina (2007) found that the model of collaborative learning with problem solving approach in the course of Accounting Theory is very effective in improving student learning achievement. Results of other studies also provide findings that are very typical to the effectiveness of collaborative learning. Yahya (2011) revealed that the teaching model of collaboration can have positive influence on achievement, interest, attention, and participation, motivation to Students learning process.

From the findings of the previous studies, it can be concluded that collaborative learning using varying methods and areas of study in general is able to give a good impact on student learning outcomes. The dynamics of learning in class is more cohesive and alive. Teachers play an active role as a facilitator where they function properly. Informal assessment process can be implemented and carried out by teachers with the availability rubric that has been made. 
However, on collaborative based learning methods applied pricipally lead to traits that reveal aspects of the method of collectivity, collaboration or teamwork, and group or grouping. Discussion method, role play, and so forth are the examples. In delivering learning materials we often plan to focus on the selection of appropriate methods for the learning process run in accordance with the achievement of the expected goals. This situation is very common and indeed deserve attention because it involves how learning steps starting from the opening until the closing is carried out.

Learning method also can not be separated from the other supporting factors that can liven up the atmosphere of learning more lively and foster positive interactions between students and teachers. One of very helpful in supporting the learning process with a collaborative approach especially in Lesson Study is to provide the material assignments in the assessment framework or with any other purpose that could bring the classroom atmosphere more dialogic and communicative among students. This task or assignment is commonly popular with what so called 'exercises'. Providing execises here is made as part of the learning process or a main core and not merely as a means of evaluation or assessment.

In the context of collaborative learning, the existence of the task or material exercises are important in order to stimulate students to think, communicate and collaborate. Collaborative side will appear at practice when this task is delivered to the student and the teacher's role as a motivator and facilitator will be apparent. At this stage the teacher will listen and watch on the process of collaborative interaction between groups and students in the group. Giving the task of this exercise must pay attention to the level of the task in order to make students feel capable, challenged and to think hard with his group.

Masaaki (2012) claimed that when student is facing a challenge or subject matter or issue and then exchanged opinions among one with the other students collaboratively they have shown mutual appreciation of each other's company. This indicates that the material or the problems given by the teacher will be responded critically and tried very hard by students to solve it. Manabu (2014) stated that there are two tasks that need to be served as exerciseswhen they want to have the process of collaborative learning and higher order thinking occur. They are Sharing Task and Task Jumping.

Sharing task is a task which form the task within students' level or students still can reach to work on it. This means that the task material can be understood by approximately $50 \%$ of the students. In this case they are able to do it. Meanwhile Jumping task is a task in which the material is a bit difficult. The level can be somewhat difficult. This type of task is given with an intention that students can think more critically and challenged so that students will experience 'leap' of learning to push them to think harder and to get something out of what is learned. Manabu (2014) revealed that by carrying out or providing collaborative learning that are appropriate to the level of students, the students are capable of above-average or even 
higher will be running in place.

In its application, the two stage of this task is presented on its core activities where the learning process is ongoing. So that teacher actually acts as a facilitator while students in groups and collaboratively do a discussion, build a dialogue and listen to each other to focus the mind on an issue or a given task. Sharing Task given a few moments after a teacher doing a review or a brainstorming in starting the learning process. Each student is given the time that has been set by the teacher to collaborate with students within their groups discussing the contents of the task. In the process, the students really have a dialogue, listen to each other or interact with each other. For those students who are below the average will feel confused or face difficulty in doing or understanding the contents of the task. But for students who are above average or even smart will find it easy to do. Here then the learning process of mutual benefit occur both for students below average or above the average.

The advantage here is that smart students will help students who are not in completing the task. Sometimes students will find it easier to understand when their friends explaining the material that they do not understand. At first glance we think that it is beneficial for students who are disadvantaged because they get an explanation of affluent students. However, the fact that the helper or students who help other students to explain the material are able to obtain benefit too. They become 'teachers' for the under average students and it gives them very strong and long lasting memery on that particular topic/issue that later can be recalled in collaborative situations. So they feel that this is their way of learning to recall basic knowledge from such sharing task.

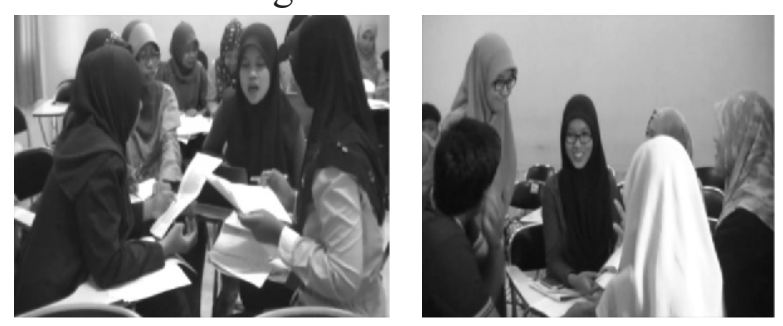

Be a 'teacher' for others Teacher: Trully a facilitator

On the level of Jumping task, each student is given the task or exercise in the form of questions or other forms where its level is much higher than sharing task. This task is presented in the second period after the teacher discusses the exercises on sharing the task. Collaborative learning using exercises on jumping material will benefit both the students who are considered as having below average competence and those who are on higher competence or ability. Low-ability students will gain a better learning leap that isprocess of learning which begins from 'development' to 'basic' not on the other way around where students all of the time obtain learning process from basic to development (Manabu: 2014).

Deriving from the characteristics of the two types of the tasks above, theory or approach proposed by Vygotsky called the Zone of Proximal Development become a reference to the provision of this leveling task. The theory reveals that learning is occuring when students handling tasks that have not been studied, but these tasks are still within the range of students' ability or the tasks are still within their zone of 
proximal development.

Zone of proximal development is the zone between the actual development level and the level of potential development. The level of actual development is seen from a child's ability in completing assignments independently. While the level of potential development is viewedfrom a child's ability to complete the task or solve the problem with the help of an adult. When included in the ZPD, then the child may actually be, but it would be optimal if an adult knows better, helping to achieve the level of actual development.

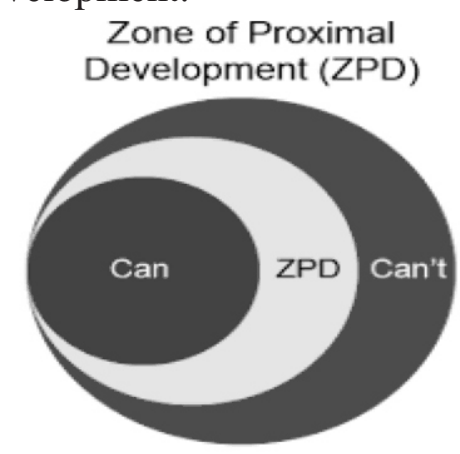

Diagram ZPD by Vygotsky

Vygotsky Specificallyargued thatpeers also have an important effect on a child's cognitive development, collaborative group work seemed to accelerate the development of children. So the purpose of ZPD is focused on social interaction that this will be able to facilitate the development of children. When students do their task on their own at schools, their development is likely to be slow. To maximize the development, students should be working with more skilled friends who can lead systematically to solve more complex problems.

Furthermore, Vygotsky stated, every human being has potential, and that potential can be actualized with mastery learning, but there is a gray area between potential and actualization. "Teachers are obliged to make the gray areas to be actualized by doing collaborative learning. In more general, there are three areas that can be categorized here. They are "can not yet do", "can do with help", and "can do alone" area. ZPD is in the area of "can do with help", this area is not a permanent area, the key is to attract learners into a "can do alone" from that zone by collaborative manner.

Both task levels especially jumping task can facilitate and accommodate this ZPD theory. This is because through its process the contribution given is able to make the students change the level of understanding. Students who are below average or low level will experienceinverse learning process that is from 'development' down to 'base'. This condition implicitely means that the low-ability students will receive instructional materials more easilywhen the presentation of the material is not presentedin rambling way (Sato, 2012). In other words as what Sato claims, the jumping task prepares for authentic learning, enhanced discourse community and ample opportunities for scaffolding for slow learners.Finally, Through jumping task students are chllenged and engaged in learning. Students might jump from actual development level to potential development level (Supriatna and Hendrayana, 2016).

Meanwhile, concerning with the sharing task, this type of task goes in line with ZPD theory where learners will not be lonely since they can work with their peers especially 
through collaborative learning. Supriatna and Hendrayana(2016) suggest that through Sharing task student is not lonely anymore. They get attention from others and could learn from others as well.This becomes a key for reflection for teachers to do further and necessary action for a change as an alternative way to plan learning process.

\section{REFERENCES}

Agustina, Linda (2013). Upaya Meningkatkan Aktivitas dan Hasil Belajar Mahasiswa melalui Pembelajaran Kolaboratif dengan Pendekatan Pemecahan Masalah. Jurnal Pendidikan Ekonomi Dinamika Pendidikan Vol 2, No 3 (2007). UNNES

Fauzi, Rizki Muhamad (2013). Pengaruh Penerapan Model Pembelajaran Kolaboratif Dalam Pembelajaran Matematika Terhadap Peningkatan Kemampuan Berpikir Kritis Matematis Pada Siswa Smp. Unpublished S-1 Thesis Universitas Pendidikan Indonesia.

Herlanti, Y. (2011). Pembelajaran Kolaboratif. yherlanti.wordpress.com

Manabu, Sato (2014) Mereformasi SekolahKonsep dan Praktik Komunitas Belajar. Pelita-JICA Tokyo

Masaaki, Sato (2012). Dialog dan Kolaborasi di Sekolah Menengah Pertama. Edisi ke Tiga. Pelita-JICA Tokyo

Supriatna, Asep and Hendrayana, Sumar: Sharing and Jumping Tasks for Enhancing Chemistry Learning at High School www.academia.edu (accessed in 21 Dec
2016)

Yahya, Islachuddin (2011). Upaya Meningkatkan Prestasi Belajar Bahasa Indonesia Dengan Menerapkan Model Pengajaran Kolaborasipada Siswa Kelas Vi SDN ABC Jakarta Pusat. Unpublished Thesis.

http://rudicahyo.com/psikologi-artikel/zoneof-proximal-development-danscaffolding-pada-teori-belajar-vygotsky/

https://penembushayalan.wordpress.com/kulia h/tokoh-dan-teori-belajar/teoripembelajaran-vygotsky/

http://nurussubahah.blogspot.co.id/2012/05/zo ne-of-proximal-development-zpddari.html 